\title{
The Role of Clerics in Confronting the COVID-19 Crisis in Iran
}

\author{
Javad Yoosefi Lebni ${ }^{1}$. Arash Ziapour ${ }^{2}$. Nafiul Mehedi ${ }^{3}$. \\ Seyed Fahim Irandoost ${ }^{4}(\mathbb{B}$
}

Accepted: 20 May 2021 / Published online: 30 May 2021

(c) The Author(s), under exclusive licence to Springer Science+Business Media, LLC, part of Springer Nature 2021

\begin{abstract}
Clerics were an authoritative and prominent group in society during the spread of the COVID-19 in Iran. Some of them contributed to social welfare services to assist Iranians. However, others engaged in improper activities, such as calling the COVID-19 pandemic a hoax, standing against the quarantine rules, questioning the scientific methods of preventing COVID-19, and offering incorrect strategies that affected prevention and treatment. Yet, clerics are powerful social assets in Iranian society who have the status to help minimize the spread and effects of pandemics upon Iranian people. As a result, their assistance and influence must be used to combat the COVID-19 crisis. This paper argues that clerics in Iran should motivate people to uphold and obey health norms in four ways: (1) health promotion and encouragement, (2) material and instrumental support, (3) spiritual support, and (4) the mobilization of people to combat the disease. Conversely, it highlights the negative roles of clerics, such as (1) opposing social restrictions and opposing the closure of religious places, (2) countering the scientific-hygienic principles appropriate to COVID-19 prevention, and (3) opposing vaccination.
\end{abstract}

Keywords COVID-19 $\cdot$ Pandemic $\cdot$ Clergy $\cdot$ Clerics $\cdot$ Iran

Seyed Fahim Irandoost

fahim.irandost@gmail.com

1 Health Promotion Research Center, Iran University of Medical Sciences, Tehran, Iran

2 Research Center for Environmental Determinants of Health (RCEDH), Health Institute, Kermanshah University of Medical Sciences, Kermanshah, Iran

3 Department of Social Work, ShahJalal University of Science and Technology, Sylhet, Bangladesh

4 Department of Public Health, School of Health, Urmia University of Medical Sciences, Urmia, Iran 


\section{Introduction}

The new coronavirus (COVID-19) broke out from Wuhan, China, and spread rapidly around the world within a short period (Bao et al., 2020; SoleimanvandiAzar et al., 2021; Yoosefi Lebni et al., 2021). Gradually, it became the world's biggest health crisis and one of the deadliest epidemics in the last century (Ferguson et al., 2020; Williams et al., 2020). Furthermore, the disease has had a significant economic effect and caused economic, social, and psychological problems in the affected countries (Li et al., 2020; Özatay \& Sak, 2020; Usher et al., 2020; Yoosefi Lebni, Abbas, et al., Yoosefi Lebni, Abbas, et al., 2020, Yoosefi Lebni, Khorami, et al., 2020).

Until April 19th, 2021, the total number of people infected with COVID-19 exceeded 142 million, and more than 3 million died of it. Iran, like other countries, is affected by the disease, and statistics show that it is one of the ten countries with the highest number of patients and deaths; on April 19, 2021, the total number of COVID-19 patients in Iran reached 2,237,000, with 66,732 deaths (Worldometer, 2020).

The role of religion in disasters and social problems has grown significantly over the last decade, and therefore, many researchers are interested in studying the role of religion and religious beliefs during disasters and destuction (Gaillard \& Texier, 2010; McGeehan \& Baker, 2017). It is because people's religious beliefs can influence how they think about disasters, how they respond to them, and even how they survive and cope with them (Gianisa \& Le De, 2018; Holmgaard, 2019; Yoosefi Lebni, Khorami, et al., Yoosefi Lebni, Abbas, et al., 2020, Yoosefi Lebni, Abbas, et al., 2020).

People have always been able to use religion to soothe themselves in times of natural and unnatural disasters and calamities, and religion has always played a crucial role in easing their miseries. The COVID-19 crisis also strengthened religious faith and spirituality (Kowalczyk et al., 2020).

Moreover, religion has been shown to have an effect on people's attitudes during a crisis (Nuryana \& Fauzi, 2020; Pirutinsky et al., 2020). In the study of Dutra $\&$ Rocha, 2020, the engagement of religious leaders to educate people has been reported as one of the crucial ways to prevent COVID-19 disease (Dutra \& Rocha, 2021). Religion played a significant role in the COVID-19 crisis in some developing countries, especially in Islamic countries. In some cases, Muslims disobeyed medical advice, claiming that God has authority over life and death, while in others, they believed COVID-19 was triggered by God's wrath on humans. As a result of these problems, people are hesitant to adhere to health norms (Hashmi et al., 2020).

In Pakistan, religious leaders have repeatedly urged people to follow the safety norms provided by the health department, especially to stay at home (Farooq et al., 2020). COVID-19 was viewed as God's wrath by some religious leaders in Ethiopia, and in Pakistan, some people considered COVID-19 as a part of the government's religious propaganda to keep them under pressure (Rafi, 2020).

With the rise in the number of patients and deaths caused by COVID-19, clerics, one of the most powerful groups in Iranian society, began to contribute to 
welfare activities and provide useful social and cultural services. However, in certain cases, their entrance challenged the medical community, leaving religious adherents torn between following the guidance of clergy and that of medical professionals. Clerics have a good political position in Iran because they can participate in most planning and policy-making processes. This paper argues that clerics in Iran should use four strategies to persuade people to pay attention to health norms: (1) health promotion and encouragement, (2) material and instrumental support, (3) spiritual support, and (4) the mobilization of people to combat the disease.

\section{The Clerics and the Crisis of COVID-19}

During the COVID-19 outbreak in Iran, clerics played two roles: they supported constructive measures to fight and prevent the disease, as well as they thwarted the attempts by health organizations and the government to control and prevent the disease with certain measures. These positive and negative actions are listed in Table 1.

\section{Social Welfare Activities of the Clerics}

\section{Health Promotion and Encouragement}

When the COVID-19 crisis hit Iran, the majority of clerics released a statement urging people to obey health guidelines and doctors' instructions in order to avoid and control the disease (Hosaini \& Marzband, 2020). Furthermore, they played an active role in encouraging people to avoid large-scale religious gatherings, such as the closing of mosques, and ceremonies, as well as motivating people to perform religious rites at home (Bozorgmehr, 2020; Chitsaz, 2020).

Table 1 Summary of Positive and Negative Contribution of Islamic Clerics regarding COVID-19

\begin{tabular}{ll}
\hline Positive contribution & Negative contribution \\
\hline Health Promotion and encouragement & $\begin{array}{c}\text { Opposing social restrictions and opposing } \\
\text { the closure of religious places } \\
\text { Countering the scientific-hygienic principles } \\
\text { of COVID-19 prevention }\end{array}$ \\
$\begin{array}{l}\text { Material and instrumental support } \\
\text { Opposing the vaccination programs } \\
\text { Spiritual Support }\end{array}$ & \\
\hline
\end{tabular}




\section{Material and Instrumental Support}

Because of their status and dignity in society, clerics gathered a large amount of material aid, such as food, and distributed it to the people. Mosques are situated in the center of Iranian society (Hosaini \& Marzband, 2020); so, it was easier for them to identify the needy. Thus, it helped the clerics to provide more material and non-material assistance to the vulnerable groups, and this was one of the positive activities of them. In many mosques and religious places, despite the closed doors, the clerics continued their social welfare activities. Furthermore, they used religious places to produce and pack disinfectants.

\section{Spiritual Support}

With the spread of the COVID-19, most people were terrified and stressed, and since religious places were closed, some clerics took measures, such as using cyberspace to portray religious places for the people and showing various types of prayers. They partially controlled the stress of religious believers (Chitsaz, 2020). Another problem was that COVID-19 patients were homesick and even scared in the hospital because they had no companions. Following the health guidelines, some clerics went to the hospitals, and sat next to the patients, and spiritually strengthened them (Qom University of Medical Sciences, 2020). Besides, after the first death caused by COVID-19, many people became concerned with how to bury the deceased. Because according to Islam, which is the common religion of the majority of Iranians, the dead must be buried in a special ceremony. They were anxious that the ceremony would not take place due to the nature of the death. But the clerics took action spontaneously and performed religious rites for the deceased. This has made it easier for families to deal with the loss of a loved one. The clerics' intervention did not stop there; they also helped the deceased's families during the grieving process, since it was sorely required for moral help.

\section{Mobilization of People to Combat the Disease}

Through their influence and powerful position in society, the clerics have been able to entice a large number of people to participate in voluntary activities to prevent and control the COVID-19. Some of these volunteers were introduced to other organizations, such as the Red Crescent, the municipality, etc., in order to disinfect and clean urban and rural roads. Others visited the hospitals to assist the nurses in caring for the COVID-19 victims. 


\section{Improper Actions and Activities of the Clerics}

Despite the supportive roles that clerics have performed, they also often played divisive roles that have the potential to make the condition much more difficult for medical professionals. In other words, clerics' efforts to battle scientific trends in the fight against this disease could exacerbate the spread.

\section{Opposing Social Restrictions and Opposing the Closure of Religious Places}

The Iranian government decided to close religious places at the onset of the COVID19 outbreak. Some clerics, however, did not accept the closing of religious institutions, so they called on their followers to assemble at the doors of religious institutions, and attempted to open the doors themselves (Jafari \& Gharaghani, 2020). Clerics and religious people believe that a religious place is a "House of Healing" and a place to find peace and control people's spiritual wellbeing. Therefore, the closure of these places will cause more harm to the religion and religious beliefs of the people and will have more consequences. In this case, they believe that the structures of these places are antibacterial and the virus is not transmitted in these places and religious ceremonies should not be closed (Chitsaz, 2020). Also, some clerics questioned the issue of quarantine and social restrictions and did not consider it necessary (Alimardani \& Elswah, 2020).

\section{Countering the Scientific-Hygienic Principles of COVID-19 Prevention}

Some clerics have played an unfavorable role in challenging scientific-health values and questioning scientific approaches for COVID-19 prevention (Ahmed $\mathrm{M}$ et al., 2020; Ghadyani et al., 2020). According to a small number of these clerics' followers, these approaches were ineffective, and they burned the book of Harrison's Principles of Internal Medicine, which is one of the most reliable medical sources in the world (Faghihi, 2020). These less-known clerics proposed treatments, such as drinking camel urine and using traditional medicine (using violet oil) (Alimardani \& Elswah, 2020), which were rejected by doctors, health officials, and all prominent clerics. In this regard, clerics criticized healthcare organizations for designing health protocols and showing a lack of commitment to spirituality and religion in the prevention and treatment of COVID-19. They stated that religion could play an important role in the prevention and treatment of COVID-19. In other words, they prioritized spiritual faith over scientific and physical measures. This posed a challenge for health planners to control the fatality of the COVID-19.

\section{Opposing the Vaccination Programs}

Some clerics opposed the COVID-19 vaccination programs, and they claimed that injecting these vaccines would cause more diseases and inconveniences, such as 
homosexuality. Some stated that the vaccines would be used to spy on Muslims and instigate them to follow Western cultures, although none of these claims are scientific and have been dismissed by other clerics (Tabrizian, 2021).

\section{Conclusion}

The COVID-19 experience in Iran demonstrates that clerics may have a significant effect on people's thoughts and behavior because of their social status and dignity. As a result, these individuals are important societal assets in society that can be effectively used during disasters, social, and health crises. But at the same time, they can act on the opposite front and contribute to disease transmission, or disrupt the scientific interventions of disease prevention and treatment.

Funding No funding was received for this study.

\section{Declarations}

Conflict of interest The authors declare they have no conflicts of interest.

Ethical Approval This article does not contain any studies with human participants or animals performed by any of the authors.

\section{References}

Ahmed, M. A., Ebrahim, Y., Shimaa, S., Safaa, A., \& Yasmin, I. (2020). COVID-19: How does religion interact with pandemic? Archives of Health Science, 4(4), 1-2. https://doi.org/10.31829/2641-7456/ ahs2020-4(1)-132

Alimardani, M., \& Elswah, M. (2020). Online Temptations: COVID-19 and Religious Misinformation in the MENA Region. Social Media+ Society, 6(3), 2056305120948251. https://doi.org/10.1177/ 2056305120948251

Bao, Y., Sun, Y., Meng, S., Shi, J., \& Lu, L. (2020). 2019-nCoV epidemic: Address mental health care to empower society. The Lancet, 395(10224), e37-e38. https://doi.org/10.1016/S0140-6736(20) 30309-3

Bozorgmehr, N. (2020). How Iran's clergy fought back against coronavirus: Clerics' acceptance of lockdown has been key to Islamic republic's battle against pandemic. https://www.ft.com/content/8e9b5 Obb-ebf7-4702-9894-1f2081ae869a, June 17.

Chitsaz, M. J. (2020). Corona and religiosity: Challenges and analyzes. Social Impact Assessment Quarterly, 1(2), 151-162. (In Persian).

Dutra, C. C., \& Rocha, H. S. (2021). Religious support as a contribution to face the effects of social isolation in mental health during the pandemic of COVID-19. Journal of Religion and Health, 60, 99-111. https://doi.org/10.1007/s10943-020-01140-2

Faghihi, R. (2020). A cleric's cure for coronavirus becomes butt of jokes in Iran. https://www.al-monitor. com/originals/2020/03/bizarre-cures-for-coronavirus-in-iran.html, March 10.

Farooq, S., Haider, S. I., Sachwani, S., \& Parpio, Y. N. (2020). Insight into COVID-19 responses and initiatives from Pakistan. Journal of the College of Physicians and Surgeons Pakistan, 30(6), 50-52. https://doi.org/10.29271/jcpsp.2020.supp1.s50 
Ferguson, N. M., Laydon, D., Nedjati-Gilani, G., Imai, N., Ainslie, K., \& Baguelin, M. (2020). Impact of non-pharmaceutical interventions (NPIs) to reduce COVID-19 mortality and healthcare demand. Imperial College London, 20, 1-20.

Gaillard, J.-C., \& Texier, P. (2010). Religions, natural hazards, and disasters: An introduction. Religion, 40(2), 81-84. https://doi.org/10.1016/j.religion.2009.12.001

Ghadyani, M., Hussain, H., Odeh, W., \& Wood, P. (2020). Responses to the COVID-19 Pandemic in Syria, Iran and Pakistan. Abdou Filali-Ansary Occasional Paper Series, 2, 1-36.

Gianisa, A., \& Le De, L. (2018). The role of religious beliefs and practices in disaster. Disaster Prevention and Management, 27(1), 74-86. https://doi.org/10.1108/DPM-10-2017-0238

Hashmi, F. K., Iqbal, Q., Haque, N., \& Saleem, F. (2020). Religious cliché and stigma: A brief response to overlooked barriers in COVID-19 management. Journal of Religion and Health, 59(6), 26972700. https://doi.org/10.1007/s10943-020-01063-y

Holmgaard, S. B. (2019). The role of religion in local perceptions of disasters: The case of post-tsunami religious and social change in Samoa. Environmental Hazards, 18(4), 311-325. https://doi.org/10. 1080/17477891.2018.1546664

Hosaini, S. H., \& Marzband, R. (2020). Strategies for health maintenance and promotion based on islamic teachings in covid-19 pandemic. Religion and Health, 8(2), 79-89. (In Persian).

Jafari, H., \& Gharaghani, M. A. (2020). Cultural challenges: The most important challenge of COVID-19 control policies in Iran. Prehospital and Disaster Medicine, 35(4), 470-471. https://doi.org/10.1017/ S1049023X20000710

Kowalczyk, O., Roszkowski, K., Montane, X., Pawliszak, W., Tylkowski, B., \& Bajek, A. (2020). Religion and faith perception in a pandemic of COVID-19. Journal of Religion and Health, 59(6), 2671-2677. https://doi.org/10.1007/s10943-020-01088-3

Li, S., Wang, Y., Xue, J., Zhao, N., \& Zhu, T. (2020). The impact of COVID-19 epidemic declaration on psychological consequences: A study on active Weibo users. International Journal of Environmental Research and Public Health, 17(6), 1-9. https://doi.org/10.3390/ijerph17062032

McGeehan, K. M., \& Baker, C. K. (2017). Religious narratives and their implications for disaster risk reduction. Disasters, 41(2), 258-281. https://doi.org/10.1111/disa.12200

Nuryana, Z., \& Fauzi, N. A. F. (2020). The Fiqh of disaster: The mitigation of covid-19 in the perspective of Islamic education-neuroscience. International Journal of Disaster Risk Reduction, 51, 101848. https://doi.org/10.1016/j.ijdrr.2020.101848

Özatay, F., \& Sak, G. (2020). What can we do to manage the economic consequences of COVID-19? Economic Policy Research Foundation of Turkey (TEPAV), Policy Note N, 202006.

Pirutinsky, S., Cherniak, A. D., \& Rosmarin, D. H. (2020). COVID-19, mental health, and religious coping among American Orthodox Jews. Journal of Religion and Health, 59(5), 2288-2301. https://doi. org/10.1007/s10943-020-01070-z

Qom University of Medical Sciences. (2020). Corona special letter. Scientific Monthly Information on Health Knowledge and Religion, 2(19), 1-31. (In Persian).

Rafi, M. S. (2020). Dialogic content analysis of misinformation about COVID-19 on social media in Pakistan. Linguistics and Literature Review, 6(2), 131-143. https://doi.org/10.32350/1lr.62.12

Soleimanvandiazar, N., Irandoost, S. F., Ahmadi, S., Xosravi, T., Ranjbar, H., Mansourian, M., \& Lebni, J. Y. (2021). Explaining the reasons for not maintaining the health guidelines to prevent COVID-19 in high-risk jobs: A qualitative study in Iran. BMC Public Health, 21(1), 1-15. https://doi.org/10. 1186/s12889-021-10889-4

Tabrizian, A. (2021). Being jabbed with COVID-19 vaccine makes you gay? An Iranian cleric thinks so. https://www.arabnews.com/node/1805771/offbeat, March 28.

Usher, K., Bhullar, N., Durkin, J., Gyamfi, N., \& Jackson, D. (2020). Family violence and COVID-19: Increased vulnerability and reduced options for support. Wiley Online Library, 29(4), 549-552. https://doi.org/10.1111/inm.12735

Williams, S. N., Armitage, C. J., Tampe, T., \& Dienes, K. (2020). Public perceptions and experiences of social distancing and social isolation during the COVID-19 pandemic: A UK-based focus group study. British Medical Journal Open, 10(7), e039334. https://doi.org/10.1136/bmjop en-2020-039334

Worldometer (2020). Coronavirus. Statistics Counters. NY: Dadax Limited. https://www.worldometers. info/coronavirus/

Yoosefi Lebni, J., Abbas, J., Moradi, F., Salahshoor, M. R., Chaboksavar, F., Irandoost, S. F., Nezhaddadgar, N., \& Ziapour, A. (2020). How the COVID-19 pandemic effected economic, social, political, 
and cultural factors: A lesson from Iran. International Journal of Social Psychiatry, 67(3), 298-300. https://doi.org/10.1177/0020764020939984

Yoosefi Lebni, J., Khorami, F., Ebadi Fard Azar, F., Khosravi, B., Safari, H., \& Ziapour, A. (2020). Experiences of rural women with damages resulting from an earthquake in Iran: A qualitative study. BMC Public Health, 20(625), 1-13. https://doi.org/10.1186/s12889-020-08752-z

Yoosefi Lebni, J., Irandoost, S. F., Mehedi, N., Sedighi, S., \& Ziapour, A. (2021). The Role of Celebrities During the COVID-19 Pandemic in Iran: Opportunity or Threat? Disaster Medicine and Public Health Preparedness. https://doi.org/10.1017/dmp.2020.498

Publisher's Note Springer Nature remains neutral with regard to jurisdictional claims in published maps and institutional affiliations. 